\title{
PROPERTIES OF TISSUE SPECIFIC MACROPHAGES BEFORE AND AFTER IN VITRO ACTIVATION
}

\author{
ŽIVANČEVIĆ-SIMONOVIĆ SNEŽANA*, INIĆ-KANADA ALEKSANDRA**, STOJANOVIĆ MARIJANA** \\ and DIMITRIJEVIĆ LJILJANA** \\ *Institute of Pathophysiology, School of Medicine, University of Kragujevac, Kragujevac, \\ **Institute of Immunology and Virology, Torlak, Belgrade
}

(Received 21. September 2003)

\begin{abstract}
Macrophages derived from different tissues: bone marrow, spleen, peritoneal cavity and alveolus, were examined from the aspects of their morphology and functional characteristics [expression of Fc receptors (FcR), phagocytic activity towards yeast particles and nonspecific esterase (NSE) content] before and after in vitro activation. Twenty four-hour-adherent cells were isolated with the aim of analyzing the characteristics of resident tissue macrophages. Following cultivation in vitro 8-day-adherent cells were used to investigate the influence of macrophage activation on their morphology and function. Morphological analysis of cell smears, performed in respect to cell size, showed significant enlargement, especially in the population of alveolar cells cultured for 8 days and activated with colony-stimulating factors (CSFs) and lymphokines. It was also demonstrated that 24-hour- and 8-dayadherent macrophages derived from different tissues exhibited similar properties. All these cells were more than 90\% FcR-positive (FcR+), NSE-positive (NSE+) and had phagocytic properties. However, within the population of alveolar macrophages there were some NSE + cells lacking FcR and phagocytic activity, even after in vitro activation. These results confirmed that the properties of alveolar macrophages differing from those of macrophages from other tissues were dependent on their microenvironment.
\end{abstract}

Key words: Fc receptor expression, nonspecific esterase, macrophage morphology, phagocytosis

\section{INTRODUCTION}

Tissue macrophages are the major component of the classical reticuloendothelial system, which is a dynamic cellular system with the potential to exert a modulatory role in inflammatory responses and tissue homeostasis. The term "macrophages" comprises a morphologically and functionally heterogeneous cell population, which differ widely with respect to size, enzyme activity, phagocytic capacity and a variety of surface markers (Walker, 1976; Lee, 1980). Their functional diversity appears to be related to their anatomical site, which indicates adaptation to local microenvironments within the various tissues. Differences in 
macrophage biochemistry, morphology and function have been extensively studied in alveolar and peritoneal macrophages but data concerning the characteristics of lymphoid tissue macrophages are rather obscure. Based on the finding that normal "resident" tissue macrophages could be activated by immunological stimuli to raise an immune response, (Snyder et al., 1982; Steeg et al., 1982), we suggested that the tissue specific difference between macrophages could be eliminated in identical culture conditions.

The aim of this study was to evaluate the functional capacity of macrophages from different tissues, and correlate the functional activities to their morphological properties. Cells were obtained from bone marrow, spleen, peritoneal cavity and alveolus. To avoid dendritic cell involvement 24-hour-adherent cells were analyzed (Steinman and Cohn, 1973). The growth and development of isolated cells was maintained by the use of L-cell line 929 conditioned medium as a source of CSFs (Suzu and Motoyoshi, 2002; Akagawa, 2002). The impact of macrophage activation on their morphology and functional capability was analyzed in the presence of Con A-stimulated spleen cell supernatant (Watson et al., 1979). The data obtained in our experimental model demonstrated tissue microenvironment dependence of macrophage morphology and function, because differences between alveolar and other tissue macrophages detected 24 hours after isolation could not be completely annulled in the presence of CSF-1 and lymphokines.

\section{MATERIALS AND METHODS}

Animals. 6-8 week old male or female mice (C57BL/6) were obtained from the Academy of Military Sciences, Belgrade.

Cell preparation. Cell suspensions were made from bone marrow, spleen, peritoneal cavity and lungs. Bone marrow (BM) was obtained from the femur by flushing the shaft from the proximal side with $1 \mathrm{ml}$ culture medium. Spleen was isolated aseptically and spleen cells (SC) were obtained by gently mincing the organ through a stainless steel mesh. The end bronchial lavage technique was performed as described by Holt (1979). Lavage fluids were obtained after the injection of $1 \mathrm{ml}$ phosphate buffer saline (PBS) via the trachea. Lung washings from 4-5 individual animals were pooled. Peritoneal cells (PC) were obtained from mice by peritoneal lavage. Peritoneal washings were withdrawn aseptically through a small incision in the lower right abdominal quadrant. After the injection of $5 \mathrm{ml}$ of PBS, the abdomen was kneaded gently and lavage fluid was collected. After isolation from different sources, the cells were centrifuged at $200 \mathrm{xg}$ for $10 \mathrm{~min}$ and suspended in RPMI 1640 medium (Gibco), containing $100 \mathrm{IU} / \mathrm{ml}$ of penicillin, 100 $\mu \mathrm{g} / \mathrm{ml}$ of streptomycin, $2 \mathrm{mM} \mathrm{L-glutamine} \mathrm{and} 10 \%$ fetal calf serum (FCS, Gibco).

Cell culture. Macrophage enrichment was achieved by a simple-one-step adherence procedure. Cell suspensions were plated into $100 \mathrm{~mm}$ plastic Petri dishes and incubated at $37 \mathrm{C}$ in $5 \% \mathrm{CO}_{2}$ in a humidified atmosphere incubator (Hereaus) for 24 hours (24-hour-adherent cells) or for 8 days (8-day-adherent cells). When the macrophages were isolated after adherence for 8 days, cultures contained $10 \%(\mathrm{v} / \mathrm{v})$ L-cell line 929 -conditioned medium as the source of CSF 
(Stewart et al., 1975). After a 96 hour-incubation with CSF, the culture medium was removed and replaced with fresh medium containing $10 \%$ supernatant for Con Aactivated spleen cells (Anderson and Gronvik 1979) and incubated for another 96 hours. After washing the monolayer with PBS in order to remove non-adherent cells 24-hour- or 8-day-adherent cells were removed from the plastic surface by incubating with PBS containing $0.02 \%$ disodium EDTA for 20 min at $4{ }^{\circ} \mathrm{C}$, and then squirting the solution on the dishes vigorously. Next, PBS was added and the remaining adherent cells were scraped off with a rubber policeman. Cells were washed twice with PBS and resuspended in RPMI 1640 medium. Cell were counted in a hemocytometer and viability was determined with $0.1 \%$ trypan blue.

Detection of Fc receptors. The EA rosette test was used to detect Fc receptors expressed on the macrophages. Equal volumes of $2 \%$ sheep red blood cells (SRBC) and inactivated anti-SRBC serum were incubated for $30 \mathrm{~min}$ at $37^{\circ} \mathrm{C}$, and then the coated red cells were washed twice in the medium. Sensitized SRBC $\left(5 \times 10^{7}\right)$ and putative macrophages $\left(1 \times 10^{6}\right)$ were centrifuged for $5 \mathrm{~min}$ at $100 \times \mathrm{xg}$ (Kedar et al., 1974). After incubation for $60 \mathrm{~min}$ at $4^{\circ} \mathrm{C}$, the number of rosette forming cells was determined. A cell with five or more attached SRBC was considered a rosette; at least 100 rosettes were analyzed in each test.

Phagocytosis. Phagocytic activity was evaluated by incubation of adherent cells with yeast particles in the presence of neutral red. After incubation for 15-20 min at $37^{\circ} \mathrm{C}$, phagocytosis was stopped by addition of EDTA. Cells were washed three times and the number of cells containing yeast particles was determined.

Cellular analysis. Cytocentrifuge prepared smears of cell suspensions were used to study the morphology of the adherent cells. The smears were air dried, stained with May Grünvald and Giemsa stain, and analyzed by light microscopy.

Cytochemical staining for nonspecific esterase. Cytocentrifuge prepared smears were fixed in $10 \%$ formalin foams, washed and air dried. The smears were stained with pararosaline in the presence of $\alpha$-naphthyl acetate as the substrate (Mueller et al., 1975). After incubation for $60 \mathrm{~min}$ at room temperature smears were washed and analyzed by light microscopy.

\section{RESULTS}

\section{Morphology of 24-hour-adherent cells}

Within the suspensions of adherent cells, macrophages were defined according to the following criteria: size and shape of the cells as well as the appearance and size of the nucleus. Nearly all isolated cells, irrespective of their tissue origin, showed macrophage morphology (more than 94.9\%) following 24 hour of cultivation in vitro (Table 1). However, significant differences in size were observed for cells originating from different sources. Thus, the highest percentage of "small" macrophages occurred within cell populations from bone marrow and spleen, while more "large" cells were present in the suspension of macrophages isolated from the lungs and peritoneal cavity. 
Table 1. Macrophage content and cell size analysis of 24-hour-adherent cells

\begin{tabular}{|c|c|c|c|c|c|c|c|}
\hline \multirow{2}{*}{$\begin{array}{c}\text { source of } \\
\text { cells }\end{array}$} & \multirow{2}{*}{$\begin{array}{c}\text { macro- } \\
\text { phage }\end{array}$} & \multicolumn{7}{|c|}{ \% of cells according to the size $(\mu \mathrm{m})$} \\
\cline { 3 - 8 } & $<15$ & $16-20$ & $21-25$ & $26-30$ & $31-35$ & $>36$ \\
\hline \hline BMC & 95.3 & 28.3 & 35.7 & 23.5 & 9.7 & 2.6 & 0.0 \\
\hline SC & 94.9 & 30.5 & 37.0 & 23.9 & 8.7 & 0.0 & 0.0 \\
\hline PC & 95.7 & 1.0 & 14.0 & 42.0 & 29.0 & 4.0 & 0.0 \\
\hline AC & 98.1 & 0.0 & 26.2 & 54.9 & 31.2 & 0.0 & 0.0 \\
\hline
\end{tabular}

*Adherent cells were isolated from the suspension of bone marrow cells (BMC), spleen cells (SC), peritoneal cells $(P C)$ and alveolar cells $(A C)$.

\section{Morphology of 8-day-adherent cells}

Macrophages of different sizes were also found in populations of 8 day cultivated cells and among lymphokine activated macrophages (Table 2). They were generally larger than 24 hour-adherent macrophages. "Large" cells predominated in the population derived from the peritoneal cavity and especially from the alveolus.

Table 2. Macrophage content and cell size analysis of 8-day-adherent cells

\begin{tabular}{|c|c|c|c|c|c|c|c|}
\hline \multirow{2}{*}{$\begin{array}{c}\text { *source of } \\
\text { cells }\end{array}$} & \multirow{2}{*}{$\begin{array}{l}\text { macro- } \\
\text { phage }\end{array}$} & \multicolumn{6}{|c|}{$\%$ of cells according to the size $(\mu \mathrm{m})$} \\
\hline & & $<15$ & $16-20$ & $21-25$ & $26-30$ & $31-35$ & $>36$ \\
\hline $\mathrm{BMC}$ & 97.8 & 5.0 & 38.0 & 30.0 & 18.0 & 7.0 & 2.0 \\
\hline SC & 95.0 & 10.4 & 15.6 & 20.8 & 37.7 & 13.0 & 1.3 \\
\hline $\mathrm{PC}$ & 98.9 & 0.0 & 9.1 & 45.5 & 41.0 & 4.6 & 0.0 \\
\hline$A C$ & 99.4 & 0.0 & 0.0 & 1.4 & 11.1 & 48.6 & 38.9 \\
\hline
\end{tabular}

*Adherent cells were isolated from the suspension of bone marrow cells (BMC), spleen cells (SC), peritoneal cells (PC) and alveolar cells (AC).

\section{Fc receptor expression, phagocytosis and NSE staining of 24-hour-adherent} cells

The functional analysis of adherent cells included the following examinations: Fc receptor expression on membrane, capability of cells to phagocytize yeast particles and presence of NSE in the cytoplasm. More than $90 \%$ of the adherent cells isolated from bone marrow, spleen and peritoneal cavity after 24 hour of cultivation expressed Fc receptors (Figure 1). These cells had phagocytic capability towards yeast particles (87.8 to $94.1 \%$ ) and contained NSE (91.0 to $96.0 \%)$. Bone marrow derived rosette-forming cells are shown in Figure 2.

Slightly different results were obtained with adherent cells isolated from lungs. Although almost all alveolar adherent cells were NSE-positive (95.5\%), only 
Acta Veterinaria (Beograd), Vol. 54. No. 1, 21-31, 2004

Zivančević-Simonović Snežana et al. Properties of tissue specific

macrophages before and after in vitro activation

some of those cells expressed Fc receptors (57.8\%) and phagocytized yeast particles $(50.0 \%)$.

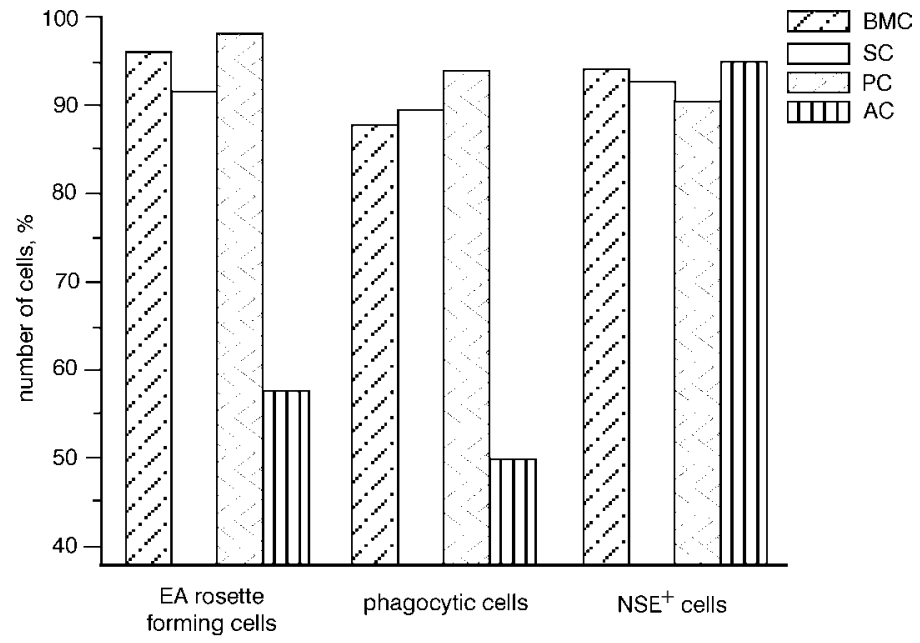

Figure 1. Fc receptor expression, phagocytic and cytochemical characteristics of 24-hour-adherent cells

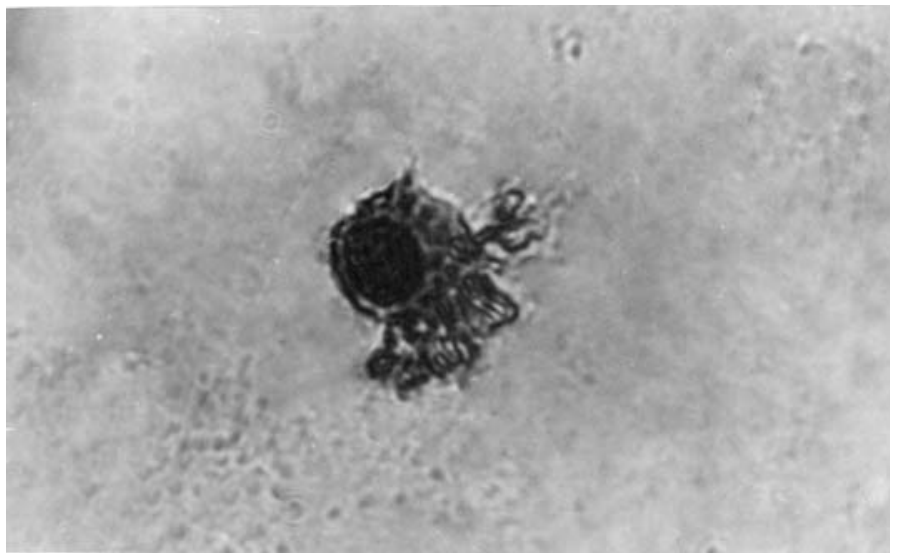

Figure 2. Rosette-forming cells derived from bone marrow (x 1000)

Fc receptor expression, phagocytosis and NSE staining of 8-day-adherent cells

It was found that $95.0 \%$ of all cultured peritoneal adherent cells expressed Fc receptors (Figure 3 ). All these cells showed phagocytic activity and contained NSE. Similar results were obtained with adherent cells isolated from spleen and 


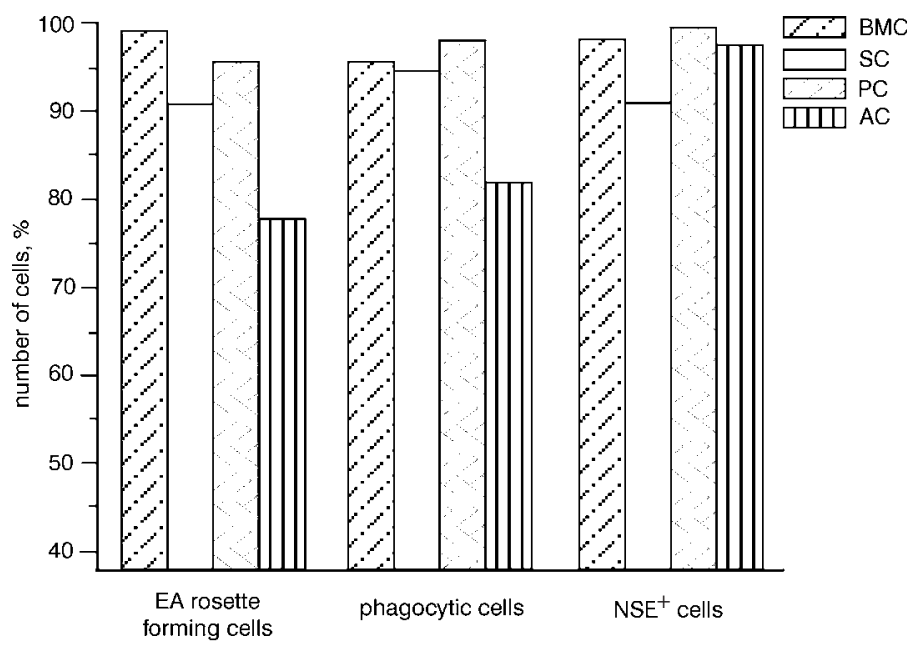

Figure 3. Fc receptor expression, phagocytic and cytochemical characteristics of 8-day adherent cells

bone marrow. There was a positive correlation between the number of FcRbearing cells, phagocytic activity and the number of NSE+ cells. Compared to the results obtained with 24-hour-adherent cells, the in vitro culture conditions and lymphokine activation increased the number of $\mathrm{FcR}+$ cells within the population of alveolar macrophages. It was clearly demonstrated that all FcR + cells were capable to phagocytize yeast particles $(77.5 \%$ and $81.6 \%$, respectively). Nevertheless, the number of FcR + and phagocytic cells was still lower than the number of NSE+ cells $(97.2 \%)$.

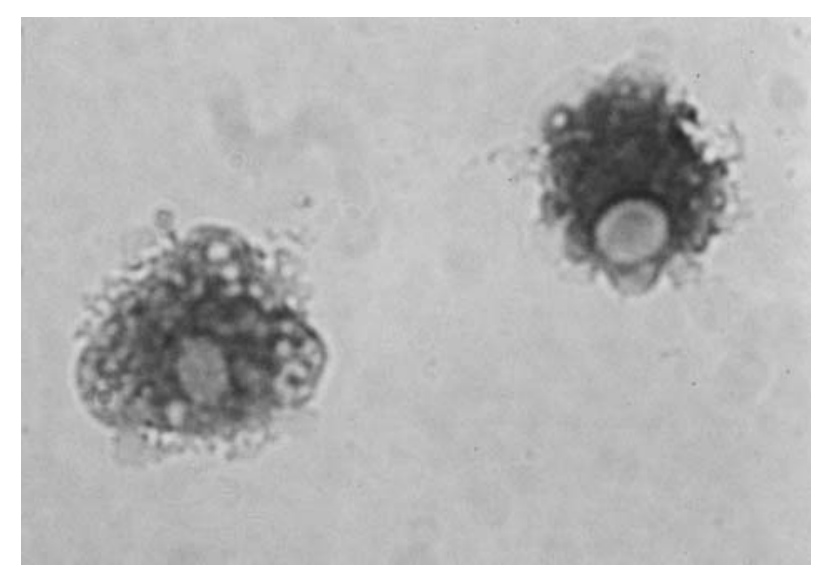

Figure 4. Adherent alveolar macrophages obtained from 8 day-old cell culture, stained for nonspecific esterase (x 1000) 
Acta Veterinaria (Beograd), Vol. 54. No. 1, 21-31, 2004

Zivančević-Simonović Snežana et al. Properties of tissue specific

macrophages before and after in vitro activation

According to our results, NSE content was much higher in alveolar macrophages (Figure 4), than in peritoneal macrophage cell populations (Figure 5) as well as in macrophages from bone marrow and spleen.

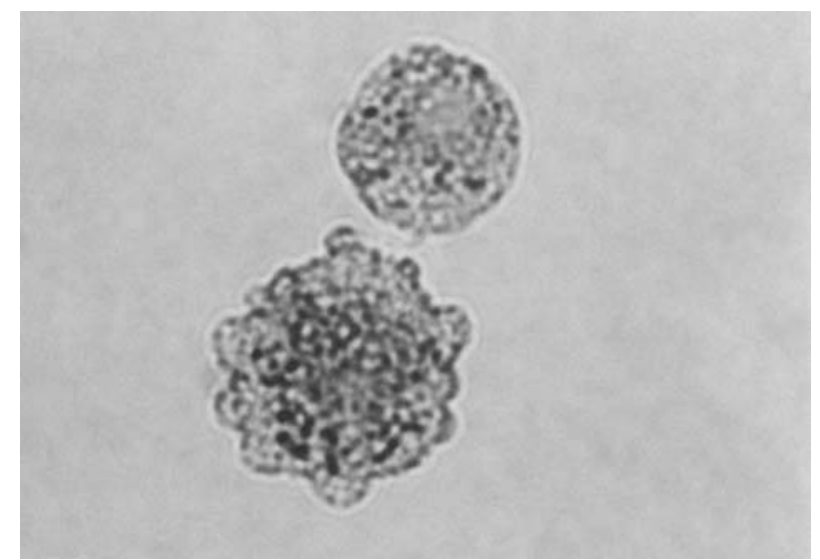

Figure 5. Adherent peritoneal macrophages obtained from 8 day-old cell culture, stained for nonspecific esterase (x 1000)

\section{DISCUSSION}

In this study we analyzed 24-hour-adherent cells to define the subpopulations of resident tissue macrophages isolated from different sources, together with 8-day-adherent cells, activated in vitro by the use of CSFs and lymphokines, because inflammatory and immunological stimuli could activate macrophages and change their characteristics (Snyder et al., 1982; Steeg et al. 1982). There are reports that macrophages, presumably of a relatively immature phenotype, can undergo DNA synthesis at the sites of inflammation in response to CSF-1 (Bitterman et al. 1985; Jutila and Banks, 1986). Although adherence to a plastic surface could change the characteristics of resident macrophages to a certain degree, cultivation in the absence of CSFs and lymphokines was used in order to classify these cells as a "resident". Macrophages isolated from the 8-day-old culture in the presence of CSF and lymphokine-containing medium were considered as "activated".

It has already been shown that macrophages in various tissues during steady state as well as at sites of inflammation are heterogeneous with respect to phenotype and function (Chan et al. 1998). Light microscopic examination of 24hour-adherent macrophages showed that they were smaller and rounder when compared with 8-day cultured macrophages, which were larger and more irregular in shape cultivated in macrophage-(M) CSF and lymphokine containing medium. In our culture conditions, peritoneal, and especially alveolar macrophages, enlarged more than bone marrow and spleen macrophages. Moreover, 8-day- 
adherent cells from the lungs contained "large" cells mainly $(87.5 \%$ larger than 30 $\mu \mathrm{m})$.

Adherent cells isolated from bone marrow, spleen and peritoneal cavity expressed consistent properties. Thus, 24-hour-adherent cells isolated from different sources, as well as 8-day-adherent cells, contained more than $90 \%$ of NSE+ cells. Although almost all adherent cells from bone marrow, spleen and peritoneal cavity were NSE+, alveolar adherent cells had the highest amount of NSE in the cytoplasm. These findings are consistent with other data regarding the lysosomal content of macrophages and indicated that the enzyme content of alveolar macrophages was higher then that of peritoneal macrophages (Cohn and Wiener, 1963).

Beside changes in cell size revealed by comparison of resident macrophages and activated macrophages, changes in FcR expression and phagocytic ability were also detected. A high percentage of cells with macrophage morphology isolated from bone marrow, spleen and peritoneal cavity expressed receptors for Fc and could phagocytize yeast particles. The culture conditions did not significantly influence FcR expression or phagocytic activity. Surprisingly, half the alveolar macrophages did not form rosettes with antibody-coated SRBC and some cells were FcR-, even after in vitro activation. This could be due to the lack of the membrane receptor for the Fc fragment of immunoglobulins or low avidity of the receptor for the appropriate antibody. It has been shown (Rhodes, 1975) that peritoneal and alveolar macrophages differ in binding of antibodies via membrane FcR and that the mean avidity of the peritoneal macrophage population was approximately three times greater than that of the alveolar macrophages. A 6-fold increase in the proportion of high avidity cells and increase in FcR expression was also reported for normal peritoneal and alveolar macrophages (Rhodes, 1975). Our results are not in full accordance with these findings, as our culture conditions enhanced the number of FcR + cells, but some (22.5\%) alveolar macrophages remained FcR-. Inability to detect FcR on alveolar macrophages could be explained by the fact that the class of receptors on these cells differs from the receptor expressed on other investigated macrophages. It was earlier shown that there are

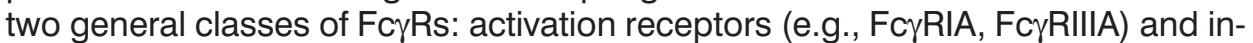
hibitory receptors (e.g., FcyRIIB), which are both present and functional in human and murine macrophages (Ravetch and Bolland, 2001). Activating FcyRs initiates a complex intracellular signaling cascade culminating in enhanced phagocytosis and secretion of inflammatory cytokines (Ravetch and Bolland, 2001). Inhibitory FcyRs, which are activated concomitantly, regulate the threshold of activation responses and ultimately terminate IgG-mediated effector stimulation (Hunter and Indik, 1998). Loor and Roelants (1974) suggested that "small" and "medium" size macrophages contained surface FcR in culture, while "large" macrophages lost these molecules, which is in accordance with the size changes of alveolar macrophages in our experiment. A high percentage of "large" cells in cultured alveolar macrophages could be the reason for the lower number of EA rosettes. It is well known that alveolar macrophages are a heterogeneous cell population and, in response to different stimuli, they mature and become functionally uniform with increased FcR avidity for cytophylic antibodies (Arend and Mannik, 1973). The re- 
sults obtained in this study were not completely in accordance with this statement, since we demonstrated that in vitro stimulation of alveolar macrophages increased their ability to form EA rosettes. Nevertheless, all cultured macrophages did not acquire EA rosette-forming activity. The number of FcR+ alveolar macrophages was correlated with the number phagocytic cells in this cell population. Only a $50 \%$ of 24 -hour-adherent cells were able to phagocytize yeast particles. It was earlier demonstrated that phagocytic ability of alveolar macrophages was less than that of peritoneal macrophages (Walker, 1976). These in vitro results are consistent with the results obtained in vivo (Poelma et al., 2002) that $70 \%$ of alveolar macrophages internalize fluorescent-labeled liposomes with a surfactant-like composition. Previous studies showed that the FcR-gamma deficient mice exhibit multiple defects in FcR-mediated effector cell responses (Takai, 1996), including absence of phagocytic activity against opsonized red blood cells by activated macrophages (Berclaz et al. 2002). In our experimental model, 8-days cultivated alveolar macrophages were less capable to phagocytize yeast particles and some of these cells were not phagocytic at all. As the alveolar macrophages are resident professional phagocytic cells, which provide a first line of host defense against microbial pathogens encountered on the respiratory surface, an inability of alveolar macrophages to phagocytize yeast particles is rather unexpected. Although the receptor for CSF is expressed in monocyte/macrophages and their progenitor cells and stimulates both the growth and development of the macrophage (Suzu and Motoyoshi, 2002) it was shown that monocytes cultured in vitro in the presence of M-CSF or granulocyte-macrophage (GM)-CSF exhibited different morphology, cell surface antigen expression, and functions (Akagawa, 2002). Bearing in mind the difference between M-CSF-induced macrophages and granulocytemacrophage colony-stimulating factor (GM-CSF)-induced macrophages in vitro (Akagawa, et al., 1988) and the necessity of GM-CSF for growth and differentiation of alveolar macrophages (Lemaire et al. 1996; Akagawa et al., 1988), the use of the L-929 conditioned medium as the source of M-CSF could be the reason for the impaired function of alveolar macrophages obtained in this study.

These data are consistent with previous studies on tissue macrophage heterogeneity and provide additional evidence for the concept that macrophages acquire unique characteristics in response to their immune microenvironment. Our experimental model favors the expression of characteristics of primarily resident macrophages as tissue differences persisted even after eight days culture in vitro.

ACKNOWLEDGEMENT

This investigation was supported by a grant 1637 from the Ministry of Science and Technology of the Republic of Serbia

\author{
Address for correspondence: \\ Ljiljana Dimitrijević, MD, PhD \\ Vojvode Stepe 458, \\ 11152 Belgrade, \\ Serbia \&Montenegro \\ e-mail: Ijiljad@EUnet.yu
}




\section{REFERENCES}

1. Akagawa KS, Kamoshita K, Tokunaga T, 1988, Effects of granulocyte-macrophage colony-stimulating factor and colony-stimulating factor- 1 on the proliferation and differentiation of murine alveolar macrophage, J Immunol, 141, 3383-90.

2. Akagawa KS, 2002, Functional heterogeneity of colony-stimulating factor-induced human monocyte-derived macrophages. Int J Hematol, 76, 27-34.

3. Anderson J, Gronvik K, Larson EL, Coutinho A, 1979, Studies on T lymphocyte activation. I Requirements for the mitogen-dependent production of T cell growth factor, Eur J Immunol, 9, 581-7.

4. Arend WP, Mannik M, 1973, The macrophage receptor for IgG: number and affinity of binding sites, J Immunol, 110, 1455-63.

5. Berclaz PY, Shibita Y, Whitsett JA, Trapnell BC, 2002, GM-CSF, via PU.1, regulates alveolar macrophage FcyR-mediated phagocytosis and the IL-18 / IFNã-mediated molecular connection between innate and adaptive immunity in the lung, Blood, 100, 4193-200.

6. Bitterman PB, Saltzman E, Adelberg S, Ferrans VJ, Crystal RG, 1984, Alveolar macrophage replication - one mechanism for the expansion of the mononuclear phagocyte population in the chronically inflamed lung, $J$ Clin Invest, 74, 460-9.

7. Chan J, Leenen PJM, Brtoncello I, Nishikawa SI, Hamilton JA, 1998, Macrophage lineage cells in inflammation: characterization by colony-stimulating factor-1 receptor (cFms), ER - MP58, and ER - MP20 (Ly - 6C) expresion, Blood, 92, 1423-31.

8. Chen BDM, Mueller M, Chou TH, 1988, Role of granulocyte/macrophage colony-stimulating factor in the regulation of murine alveolar macrophage proliferation and differentiation, $\mathrm{J} I \mathrm{mmunol}$, $141,139-44$.

9. Cohn ZA, Wiener E, 1963, The particulate hydrolases of macrophages. I Comparative enzymology isolation and properties, $J$ Exp Med, 118, 991.

10. Holt PG, 1979, Alveolar macrophages. I A simple technique for preparation of high numbers of viable alveolar macrophages from small laboratory animals, $J$ Immunol Meth, 27, 189-98.

11. Hunter S, Indik ZK, Kim MK, Cauley MD, Park JG, Schreiber AD, 1998, Inhibition of Fcã receptor- mediated phagocytosis by a nonphagocytic Fcã receptor, Blood, 91, 1762-8.

12. Jutila MA, Banks K, 1986, Locally dividing macrophages in normal and inflamed mammary glands, Clin Exp Immunol, 66, 615-24.

13. Kedar E, de Landazuri MO, Fahey JL, 1974, Comparative studies of immunoglobulin receptors and antibody - dependent cell cytotoxicity (ADCC) in rat lymphoid organs, J Immunol, 112, 37-46.

14. Lee $K C, 1980$, On the origin and mode of action of functionally distinct macrophage subpopulations. Mol Cell Biochem, 30, 39-55.

15. Lemaire I, Yang H, Lauzon W, Gendron N, 1996, M - CSF and GM-CSF promote alveolar macrophage differentiation into multinucleated giant cells with distinct phenotypes, J Leukoc Biol, 60, 509-18.

16. Loor F, Roelants GE, 1974, The dynamic state of macrophage plasma membrane. Attachment and fate of immunoglobulin, antigen and lectins, Eur J Immunol, 4, 469.

17. Mueller J, Del Re GB, Buerki H, Keller HU, Hess MW, Cottier H, 1975, Nonspecific acid esterase activity: a criterion for differentiation of T and B lymphocytes in mouse lymph nodes, Eur J Immunol, 5, 270-4.

18. Poelma DLH, Zimmermann LJI, Scholten HH, Lachmann B, van Iwaarden JF, 2002, In vivo and in vitro uptake of surfactant lipids by alveolar type II cells and macrophages. AJP - Lung Cellular and molecular physiology,, 283, L648 - L654.

19. Ravetch JV, Bolland S, 2001, IgG Fc receptors, Annu Rev Immunol, 19, 275 - 90.

20. Rhodes J, 1975, Macrophage heterogeneity in receptor activity: the activation of macrophage Fc receptor function in vivo and in vitro. J Immunol, 114, 976 - 81.

21. Snyder DS, Seller DI, Unanue ER, 1982, Prostaglandins modulate macrophage la expression. Nature, 299, 163-5.

22. Steeg PS, Moore RN, Johnson HM, Oppenheim JJ, 1982, Regulation of murine la expression antigen by a lymphokine with immune interferon activity, J Exp Med, 156, 1780-93. 
Acta Veterinaria (Beograd), Vol. 54. No. 1, 21-31, 2004

Zivančević-Simonović Snežana et al. Properties of tissue specific

macrophages before and after in vitro activation

23. Steinman RM, Cohn ZA, 1973, Identification of novel cell type in peripheral lymphoid organs of mice. I. Morphology, quantitation, tissue distribution, J Exp Med, 137,1142-62

24. Stewart CC, Lin HS, Adles C, 1975, Proliferation and colony - forming ability of peritoneal exudate cells in liquid culture, J Exp Med, 141, 1114-32.

25. Suzu S, Motoyoshi K, 2002, Signal transduction in macrophages: negative regulation for macrophage colony-stimulating factor receptor signaling, Int J Hemat, 76, 1-5.

26. Takai T, 1996, Multiple loss of effector cell functions in FcR gamma - deficient mice, Int Rev Immunol, 13, 369-81.

27. Walker WS, 1976, Functional heterogeneity of macrophage, In "Immunobiology of the macrophage", (D.S. Nelson, ed.), Academic Press, New York, 91.

28. Watson J, Gillis S, Marbrook J, Mochizuki D, Smith KA, 1979, Biochemical and biological characterization of lymphocyte regulatory molecules, I. Purification of a class of murine lymphokines. $J$ Exp Med, 150, 849-61.

\title{
KARAKTERISTIKE TKIVNO SPECIFIČNIH MAKROFAGA PRE I POSLE AKTIVACIJE IN VITRO
}

\author{
ŽIVANČEVIĆ-SIMONOVIĆ SNEŽANA, INIĆ-KANADA ALEKSANDRA, \\ STOJANOVIĆ MARIJANA i DIMITRIJEVIĆ LJILJANA
}

\section{SADRŽAJ}

Morfološke i funkcionalne karakteristike makrofaga izolovanih iz različitih organa: kostne srži, slezine, peritonealne šupljine i alveola ispitivane su pre i posle aktivacije u in vitro uslovima. Da bi se ispitale kakakteristike makrofaga koji se nalaze $u$ ispitivanim tkivima analizirane su adherentne ćelije dobijene nakon inkubacije od 24 časa. Uticaj aktivacije makrofaga na njihovu morfologiju i funkciju (ekspresiju Fc receptora, sposobnost fagocitoze čestica kvasca i sadržaj enzima nespecifične esteraze) ispitivan je nakon kultivisanja adherentnih ćelija u toku 8 dana. Morfološkom analizom utvrđeno je značajno povećanje veličine alveolarnih makrofaga kultivisanih tokom 8 dana u prisustvu faktora koji stimulišu rast kolonija i limfokina. Pokazano je da adherentne ćelije iz različitih tkiva izolovane nakon 24 sata i 8 dana imaju slične funkcionalne karakteristike. Više od $90 \%$ tih ćelija je eksprimiralo Fc receptore, imalo sposobnost fagocitoze i sadržavalo nespecifičnu esterazu. Međutim, u populaciji alveolarnih makrofaga, pre kao i nakon in vitro aktivacije, utvđeno je prisustvo ćelija koje su sadržavale nespecifičnu esterazu u citoplazmi, ali nisu eksprimirale Fc receptore, niti su imale sposobnost fagocitoze. Ovi rezultati potvrđuju da su karakteristike alveolarnih makrofaga u odnosu na makrofage iz drugih tkiva zavisne od njihovog mikrookruženja. 